\section{A Paz como Fator de Aprendizado no Ambiente Escolar}

Ensaio apresentado no IX FÓRUM REGIONAL DE SUSTENTABILIDADE: desenvolvimento regional e educação para a paz, realizado no Campus da FACULDADE AGES nos dias 19, 20 e 21 de novembro, Paripiranga, Bahia.

\section{Resumo}

Este trabalho abordou a seguinte temática: a paz como fator do aprendizado no ambiente escolar. O texto foi estruturado em cinco seções: capítulo um abordando a violência em seus conceitos gerais, 0 segundo capítulo focando violência escolar, o terceiro capítulo apresentando a relação entre escola e educação, e o quarto, a pesquisa de campo realizada. O objetivo deste trabalho consistiu em levantar, na literatura específica, histórico, causas e possíveis soluções até agora sugeridas por autores pertinentes para o problema da violência, ou seja, para o estabelecimento da paz no ambiente escolar. A justificativa para a escolha do tema consistiu no interesse em investigar a questão da violência no ambiente escolar e de forma a substituir a violência pela paz. A conclusão foi que, para resolver esse impasse, é preciso plano de ação integral, afetividade, cumplicidade, solidariedade e muito amor.

Palavras-chave: Paz; Ambiente escolar; Aprendizado.

\section{Abstract}

This study addresses the following theme: Peace as a learning factor in the school environment. The text is divided into five sections: The first chapter addresses violence in general, the second chapter focuses on school violence, the third chapter shows the relationship between school and education, and the fourth chapter discusses completed field research. The objective of this work was to investigate literature, history, causes, and possible solutions so far suggested by relevant authors to the problem of violence; that is, for the establishment of peace in the school environment. The rationale behind the choice of this subject came from an interest in investigating the issue of violence in the school environment and how to substitute violence for peace. The final conclusion was that to resolve this impasse it takes a comprehensive action plan filled with affection, complicity, solidarity and ample love. Peace; School environment; Learning.

Keywords: Peace; School environment; Learning.
Prof. Dr. Francisco das Chagas Barbosa Brandão

Professor Colaborador na Universidade Estadual do Maranhão. Programa Darcy Ribeiro. Mestre em Teologia, Doutor em Educação.

E-mail: franbran58 @hotmail.com. 
Bem-aventurados os que promovem a paz, alimentam sentimentos de benquerença, desarmam espíritos exaltados, cultivam o cuidado de uns para com os outros e suscitam amor nos corações. Estes serão os primeiros cidadãos do novo Céu e da nova Terra

(Leonardo Boff, 1990)

Meio homem, meio lobo

Hoje eu vi bem perto
lobo, que há em mim
Há em todo homem
Meio lobo, meio homem
Cultiva o homem
Que há no lobo
E o lobo não devorará
O homem
Cultiva o lobo
Que há no homem
E o lobo devorará
O homem, que há no lobo.
Meio homem, meio lobo
Parece bobo, mas é real
(Fernando Anthony Brandão, 2016)

\section{Introdução}

Grandes pensadores e líderes religiosos do mundo inteiro proclamaram e proclamam que a humanidade terá muito mais chance de encontrar a felicidade se acreditar em valores como: democracia, justiça, paz, convivialidade e altruísmo, entre outros. Dentre imagens de líderes que nos motivam, perfilam-se pessoas como Ghandi, Madre Teresa, Che Guevara, Ir. Dorothy e, sem dúvida, São Francisco de Assis como um dos maiores expoentes.

Apesar dessa afirmação tratar-se de uma grande verdade, a era moderna marcada pelo cientificismo e pelo império da razão, cujos inúmeros benefícios inegáveis tornou a estada neste planeta mais confortável, ela não se tornou, porém, mais prazerosa ou harmoniosa. Por exemplo, a comunicação e a informação entre as pessoas, hoje, podem ocorrer por meio do computador, ou seja, da internet. Porém, essas mesmas pessoas são privadas do contato direto com pessoas, lugares, objetos, sensações, deixando de interagir com o mundo real. Daí a falta de afetividade, de solidariedade, de amor.

Diante de tais ausências, a violência encontrou uma "brecha" e se infiltrou na sociedade por intermédio das pessoas. Virou sensacionalismo e a mídia, lamentavelmente, deleita-se em expor com rigor preciso de detalhes, sem focar as razões e os riscos da violência. Não provocam uma opinião pública, mas uma comoção pública (MÜLLER, 1995, p. 9). Assim, tem-se que a violência não é um incidente, ela é um fato decorrente do desenvolvimento da civilização e deve ser tratada com atenção, para que não se alastre mais do que seu presente percentual.

A lamentável realidade: tanto o Brasil quanto alguns países da América Latina são herdeiros de um legado bélico. A mesma razão humana que é capaz de projetos que favorecem a qualidade de vida, como a descoberta de remédio, é capaz de criar armas e destruir nações, dizimando a vida e a esperança.

Determinou-se que a violência é um constrangimento exercido sobre alguma pessoa para obrigá-la a fazer ou deixar de fazer um ato qualquer. Portanto, a violência subentende uma disputa de poder. Aquele que melhor usar as técnicas de coação terá o poder sobre o outro. Ao contrário da paz - ausência de violência e guerras - praticada por quem usa as "técnicas do coração".

A violência existe desde que o ser humano se organizou em sociedade. Ela não é um fenômeno dos dias de hoje. Ela sempre existiu, provavelmente até como uma forma de sobrevivência dos seres vivos: a lei do mais forte. Assim, entende-se que as causas da violência se resumem em obter o poder: físico, psicológico, econômico ou social sobre uma pessoa, um grupo ou uma nação.

Nas suas consequências, encontramos a perda de valores do homem civilizado: a igualdade, 
a fraternidade e a liberdade. Desta forma, a violência deixou de ser uma condição de sobrevivência para se tornar um meio de obter o poder, um meio de dominar o outro. E esse jogo de poder está em todas as relações sociais: patrões e empregados, marido e mulher, pais e filhos, gangues rivais, traficantes e dependentes, corruptos e corruptores, professores e alunos etc.

Quanto ao último exemplo, observa-se que, atualmente, um dos temas que vem despertando, cada vez mais, o interesse de profissionais das áreas de educação e saúde em todo o mundo é, sem dúvida, o da violência escolar. Não se trata de um problema recente, nem de um fenômeno desconhecido. Existe desde que a instituição escolar passou a existir e constituir-se como local de aprendizagem, onde os alunos deveriam adquirir valores e normas e construir, positivamente, sua personalidade e identidade. Por essa razão toma-se relevante a preocupação com as questões relacionadas à violência dentro desse ambiente onde se processa a construção de personalidades.

Segundo Lopes Neto (2005), a violência nas escolas é um problema social complexo e delicado, classificado como grave. Ainda complementa que:

A violência escolar diz respeito a todos os comportamentos agressivos e anti-sociais, incluindo os conflitos inter pessoais, danos ao patrimônio, atos criminosos, etc. muitas dessas situações dependem de fatores externos, cujas intervenções podem estar além da competência e capacidade das entidades de ensino e de seus funcionários. Porém, para um sem número delas, a solução possível pode ser obtida no próprio ambiente escolar. (LOPES NETO, 2005, p. 165)

A violência escolar é caracterizada pela agressividade, ou seja, uma forma de conduta com a intenção de ferir alguém, tanto a nível psicológico quanto físico. Isso aponta para a intencionalidade do ato agressivo, quando o indivíduo procura obter algo, coagir alguém para poder demonstrar a sua força e o seu poder.
Pelo evidenciado, tem-se que, nos últimos anos, a violência tem sido experimentada também como um problema educacional, seja por sua emergência dentro da própria comunidade escolar - violência na escola - seja pela consciência das relações que se estabelecem entre o fato social e a educação - violência da escola. Assim, a questão da violência no meio escolar vem se transformando em pauta obrigatória na agenda pública.

Porém, nesse momento de transição de educação das crianças, observa-se que muitas famílias não se sentem em condições de impor limites aos filhos, ou por não saberem bem como fazê-lo, ou por não estarem dispostas a repetir a educação repressora que tiveram.

Alguns argumentam que as crianças ainda são muito pequenas para entender certas regras, permitindo, então, que elas façam tudo o que tiverem vontade. O grande problema é que, para a grande maioria dos pais, filhos com 10 anos ainda são considerados crianças. A escola, por sua vez, também em sua grande maioria, não impõe limites, gerando desrespeito entre professores e alunos.

O problema maior, então, consiste em saber estabelecer limites entre práticas repressoras e as consideradas alternativas, afinal, é importante estabelecer limites às crianças nesta sociedade tecnológica e rebelde, caso contrário, a indisciplina como um dos fatores geradores da violência será predominante.

Pelo elucidado, decidiu-se, neste trabalho, discorrer sobre paz e violência na escola sob o tema: "A paz como aprendizado no ambiente escolar."

Tendo-se que violência e paz se relacionam intimamente no ambiente escolar, o problema de pesquisa se resume na seguinte questão: como se poderia reverter a violência de forma que a paz volte a reinar no ambiente escolar e se torne um fator de aprendizado?

Como hipótese, tem-se que a violência, o individualismo, a exclusão declarada e velada, a destruição familiar, dentre tantos outros males, estão entrelaçados. Egoísmo, disputas, 
opressão, exclusão e privatização de afetos são temas que precisam ser seriamente discutidos e conscientizados diante da necessidade do resgate de valores práticos, tais quais: companheirismo, cooperação, apoio mútuo, solidariedade, afetividade, partilha e amor (BRANDÃO, 1995).

O trabalho tem como objetivo geral levantar, na literatura específica, o histórico, as causas e possíveis soluções até agora sugeridas por autores pertinentes para o problema da violência, ou seja, para o estabelecimento da paz no ambiente escolar.

Para tanto, fez-se necessário estabelecer objetivos específicos, tais quais:

- Investigar a violência em seus conceitos gerais e no ambiente escolar: fatores de risco (preconceito e violência), nível socioafetivo e aspectos sociopsicológicos.

- Levantar conjecturas e premissas sobre a paz (escola, família, comunidade, sociedade);

- Buscar soluções encontradas até o presente momento no sentido de, se não erradicar, pelo menos amenizar o problema da violência no ambiente escolar;

- Ilustrar a teoria levantada com uma pesquisa de campo.

Não se pode deixar de reconhecer que, entre os fatores que exercem influência educativa na formação da personalidade do indivíduo, a família e a escola ocupam um lugar imprescindivel e indissociável.

\footnotetext{
Apesar de possuírem características e possibilidades diferenciadas, essas instituições, com bastante frequência, superpõem-se e se complementam, atingindo ambas a conduta do indivíduo de tal modo que não se pode abordar o seu desenvolvimento e a sua educação sem tê-las em conta. (PORTELA, 2004, p. 87)
}

As influências educativas da escola fazem parte do grupo de normas institucionalizadas, uma vez que são orientadas por regulamentos e atividades programadas, transcendendo, assim, os marcos da interação espontânea. Já as influências da família se exercem por vias não sistematizadas, ou seja, informalmente.

A educação familiar forma o caráter e o código de valores da criança através dos modelos de comportamentos da família e do meio social no qual ela está inserida. E a escola, por sua vez, tem como função a transmissão planificada dos conhecimentos acumulados pelo ser humano ao longo de sua história e que compõem a cultura em que a sociedade está imersa. Se a criança vive num ambiente hostil, onde a agressividade é uma forma de sobrevivência adaptativa, cabe à escola ensiná-la a discriminar onde e quando essa agressividade é necessária. E mais, ensinar formas alternativas de comportamento adaptativos mais adequados e produtivos para si mesma e para a sociedade.

Assim sendo, a justificativa para este trabalho encontra-se no interesse em pesquisar sobre o assunto por acreditar que a violência, como problemática mundial encontrada em todas as escolas e que vem se disseminando largamente nos últimos anos, tem solução. Ou seja, antes, a escola se traduzia em sinônimo de disciplina, tranquilidade e saber como transmissora de cultura às pessoas em prol da sociedade. Mas, hoje, lamentavelmente, foi contaminada pelos "vírus" da violência. Assim, no sentido de participar desse novo desafio da agenda escolar, ao lado de tantos problemas que a escola enfrenta, como o analfabetismo e a evasão escolar, a educação de jovens e adultos, a exclusão, dentre outros, surgiu o interesse em investigar a questão da violência no meio escolar. Lembrando que, pela constatação científica, a violência tem sido um fenômeno de interesse mundial, tem-se como uma obrigação e dever participar de sua transformação. Essa participação se resume em descobrir ações que possam ser tomadas no sentido de suprir, ou pelo menos reduzir, o sofrimento gerado pela violência.

A metodologia privilegiada foi a pesquisa bibliográfica, que "é desenvolvida a partir de material já elaborado, constituído principalmente de livros e artigos científicos" (GIL, 2002, p. 48). Cabe ressaltar que a importância da 
revisão bibliográfica "consiste no fato de que todo enunciado observacional deve ser sempre interpretado" (DEMO, 1995, p. 25).

Na pesquisa de campo foram coletados dados suficientes para demonstrar os fenômenos sem que o pesquisador interfira, como afirma Andrade (2003, p. 124): "A pesquisa de campo assim é denominada porque a coleta de dados é efetuada em campo, onde ocorrem espontaneamente os fenômenos, uma vez que não há interferência do pesquisador sobre eles".

\section{A Violência}

Neste capítulo inicial, abordou-se a violência em seus conceitos gerais.

\section{Conceitos e Definições}

A violência se traduz em "[...] atos intencionais que se caracterizam pelo uso da força, em situações de conflito, de transgressão às leis que visam o bem comum e do predomínio da crueldade sobre a solidariedade no convívio humano" (COSTA apud OSÓRIO, 2000, p. 3).

O termo violência é usado para exprimir qualquer abalo ou perturbação da realidade, como o palavrão, a indisciplina, a rebeldia e a incivilidade.

Violência gera violência, este é um truísmo que por mais que seja anunciado, a ponto de tomá-lo um lugar comum ainda não parece ter sido assimilado pelos diferentes extratos sociais em que se dispõe a humanidade. (OSÓRIO, 2000, p. 3)

Disciplina, segundo o Dicionário Aurélio Eletrônico - Século XXI (1999), é um:

\footnotetext{
[...] regime de ordem imposta ou livremente consentida, que convém ao funcionamento regular de uma organização, a observância de preceitos ou normas, submissão a um regulamento e, ainda, relações de subordinação do aluno ao mestre ou ao instrutor.
}

E "indisciplina", segundo o mesmo dicionário, é o "[...] procedimento, ato ou dito contrário à disciplina; desobediência; desordem; rebelião".
Sabe-se, entretanto, que o objetivo do dicionário é elucidar o significado do verbete sem a pretensão de explicar sua existência. Porém, mais que conhecer seu significado, interessa buscar compreender o porquê da existência do fenômeno e mais, o porquê do aumento significativo desse fenômeno/comportamento que vem sendo alvo de comentários, discussões e estudos em diferentes níveis, pois muitas escolas - e até professores - defendem que a indisciplina é um fator pura e simplesmente causado pela falta de educação moral que deveria ter sido feita pela família.

Porém, há controvérsias, pois é facilmente perceptível que a indisciplina tem diferentes fatores causais, mesmo internos à escola. Antunes (2005) ressalta que, ao se procurar o significado da palavra disciplina, observa-se em sua etimologia a ideia de "educar", "instruir", "aplicar" e "fundamentar" princípios morais e que seu antônimo é "desobediência", "confusão" ou "negação da ordem". Ampliando o sentido do termo, tem-se a ideia de "ordem", "firmeza", "obediência às regras" e, portanto, quando ela inexiste, tornam-se necessários a culpa, o castigo ou a penitência. Mas será isso mesmo? Essa reflexão etimológica simboliza efetivamente a indisciplina que se enfrenta? Não seria melhor dizer que disciplina é uma relação de afeto e respeito, uma ação recíproca de cumprimento de normas?

Segundo o mesmo autor, para que essa disciplina desejável se possa construir, torna-se imperioso indagar: Qual disciplina efetivamente se busca? Essa resposta necessita passar por uma desconstrução da ideia geral para a análise de situações específicas. Existe, por exemplo, uma disciplina em relação ao tempo: cumprir horários, acatar prazos, entregar tarefas nos momentos estabelecidos, planejar a duração de ações e discutir cronogramas. E outra entre disciplina e espaço: respeitar locais, saber guardar as coisas, retirá-las e devolvê-las ao seu lugar de origem, ocupar espaços definidos e manter-se em ordem nestes. É também essencial que se analise a disciplina em relação ao outro, às pessoas: saber esperar sua vez, respeitar a pergunta do colega, mostrar-se educado em 
relação às diferenças, compreender a individualidade e libertar-se de estereótipos. Uma disciplina que efetivamente se deseja construir avança, também, em sua relação com a aprendizagem: é necessário saber usar a memória, evoluir na expressão da linguagem, administrar estados de emoção, concentrar-se e diferenciar o descrever do analisar - o comparar do classificar e o deduzir do observar. Será que, muitas vezes, por não se conhecer bem, essas outras indisciplinas não são promovidas? Tal como em todo jogo amigável, é essencial que, ao discutir as muitas disciplinas, definam- se as sanções; jamais culpas, castigos ou penitências.

Antunes (2005) afirma que os currículos são amparados por três objetivos pelos quais a escola existe (epistemológico, socializador e profissionalizante), que se resumem em ensinar a verdade, a beleza e a justiça. Não se pode permitir que a indisciplina seja um impedimento para que o papel da escola seja cumprido, permitindo, desta forma, o estabelecimento da violência. A relação entre indisciplina e violência é saber separar um assunto do outro, pois não será através da violência que o problema da indisciplina será resolvido, aliás, esta transpõe o próprio espaço da escola.

Para esse autor, no caso, faz-se necessária a intervenção imediata de autoridade pertinente que está mais habilitada e preparada para combater a violência em si.

O autor termina sua esclarecedora palestra com um poema do poeta Eduardo Alves da Costa (COSTA apud ANTUNES, 2005, CD-ROOM), considerado digno de nota por sua grande importância, para resumir o tema indisciplina:

Na primeira noite tiram uma flor do meu jardim e eu não digo nada, na segunda noite tiram todas as flores do meu jardim e como eu não disse nada, eu não digo nada, na terceira noite invadem a minha casa esmagam meu canteiro matam o meu cachorro, arrancam minha liberdade pela garganta e como eu não disse nada eu nada direi.

Esse poema sintetiza em poucas palavras a ideia central que rege o tema da disciplina e indisciplina, questão abordada com integral seriedade, exigindo que se cumpram as regras desde o primeiro instante, caso contrário, nada mais resta fazer, a não ser lamentar não ter agido com determinação no momento certo.

Os dicionários, em geral, trazem basicamente a noção de que a violência é algo que ocorre quando as pessoas perdem a cabeça e partem para a agressão física: "[...] ato contrário à razão, à justiça ato, veemente, resultante do emprego da força para a solução de qualquer conflito humano, seja individual ou coletivo" (OSÓRIO, 2002, p. 3).

Para esse autor, essa definição é insuficiente e restrita para aprofundar o assunto, ou seja: "violência é tudo aquilo que fere, destrói, agride ou machuca as pessoas, ações que não preservam a vida ou prejudicam o bem estar tanto individual quanto coletivo" (OSÓRIO, 2000, p. 3-4).

A violência também pode ser definida como: "[...] uso da força física e do constrangimento psíquico para obrigar alguém a agir de modo contrário à sua natureza e ao seu ser. A violência é violação da integridade física e psíquica, da dignidade humana de alguém" (CHAUÍ, 1995, p. 337).

É fácil observar como a violência está em voga:

Toda vez que ligamos a TV, o rádio, abrimos um jornal ou uma revista certamente encontramos alguma notícia que nos faz pensar: 'quanta violência, onde é que isso vai parar?' Cada vez mais, os meios de comunicação deixam explícito que, onde quer que estejamos, independente de raça. Idade, sexo, grau de instrução ou classe social, estamos vulneráveis à violência, obrigando-nos a constatar que ela invadiu todas as áreas da vida e das relações do indivíduo. (OSÓRIO, 2000, p. l)

Segundo esse autor:

Este movimento, ao mesmo tempo que traz à tona essa questão tão séria, pode propiciar uma visão distorcida da realidade. O uso excessivo e indiscriminado de conceitos como agressividade, violência e 
agressão, acaba por banalizá-los, e qualquer coisa que não agrade ou não esteja de acordo com o que as pessoas querem, pode ser considerado 'uma violência'. Além disto, o grande destaque que se dá a acontecimentos extremos na mídia, sem a contextualização necessária do que está sendo noticiado com todos os fatores que propiciaram a eclosão da violência, contribui para que esta seja tida como algo que acontece apenas em situações extremas e que ela seja praticada por pessoas 'desumanas', 'más', 'doentes', ou 'loucas', quando isto está longe de ser a realidade. (OSÓRIO, 2000, p. l)

O mesmo autor esclarece que a violência pode ser:

- Macro: quando suas consequências atingem grande número de pessoas, por exemplo:

- o crime organizado;

- a fome, corrupção e exclusão.

- Micro: quando suas consequências são sentidas nas relações cotidianas, pessoais, nos indivíduos, por exemplo:

- agressão verbal e física;

- "pressão da turma".

Para esse autor, a preocupação com a expressão "macro" da violência na sociedade atual e todas as ações que vêm sendo realizadas pelos mais diversos grupos da sociedade, no sentido de denunciar essa situação e exigir atitudes eficazes que a solucionem, são evidentes e necessárias:

Mas, se destacamos e nos preocupamos apenas com esse aspecto da violência, corremos o risco de deixar de lado a 'violência nossa de cada dia', aquela que cometemos em nossa casa, escola, trabalho, com nossos familiares, amigos, vizinhos e com nós mesmos. Estas expressões 'micro' da violência parecem inofensivas, se comparadas à violência que a mídia noticia, mas em sua essência, elas podem ser tão nocivas quanto. Uma reflexão sobre as causas da violência, como ela se ma- nifesta e quais suas consequências não pode ser reduzida a explicações superficiais e simplistas que levam a ações imediatistas, que podem até maquiar, mas não chegam a transformar suas verdadeiras causas. (OSÓRIO, 2000, p. 2)

Tem-se que essa reflexão citada pelo autor é o primeiro passo na direção às mudanças e possibilita que cada um comece por fazer a sua parte.

\section{Relações Humanas x Violência}

Nas relações humanas:

[...] a violência manifesta-se através de comportamentos e ações que as pessoas realizam nas interações estabelecidas nas mais diversas áreas que atuam, por isto, faz-se necessária a delimitação de parâmetros que permitam classificar as ações e os comportamentos como violentos ou não violentos. (OSÓRIO, 2000, p. 4)

Conforme esse autor, a violência fere, destrói, agride ou machuca; são ações que não preservam a vida e/ou prejudicam o bem-estar tanto individual quanto social. Existem inúmeros fenômenos que correspondem a essa definição, conforme a classificação do autor:

- Física: quando ações ou comportamentos põem em risco a integridade física do indivíduo, como soco, chute, uso de armas;

- Simbólica: quando as ações e os comportamentos trazem riscos à integridade psíquica e emocional do indivíduo, como ironia, intimidação, humilhação;

- Intencional: quando a pessoa que comete o ato violento tem a intenção e sabe que está agredindo outra pessoa ou grupo, como briga, xingamento;

- Não intencional: quando a pessoa que comete o ato violento não quer ou não tem a intenção de cometê-lo, como uma falta mais violenta em um jogo de futebol; machucar alguém em um acidente de trânsito etc. 
Para o autor, todo ser humano é potencialmente violento, uma vez que tem a capacidade de emitir comportamentos violentos, mas sua violência latente pode não se manifestar se não houver estímulos suficientes para desencadeá-la. Desta forma, qualquer pessoa pode matar alguém, caso seja necessário, em legítima defesa ou para salvar uma vida.

\section{Exemplos de Fatores que Desencadeiam aViolência}

Para Kusnetzoff (apud OSÓRIO, 2000, p. 13), as ações são resultados da ação de vários fatores que interagem entre si, produzindo, dessa maneira, um condicionamento mútuo e, às vezes, extremamente complexo. É impossível afirmar que determinado acontecimento, necessariamente, pode desencadear um comportamento agressivo em todas as pessoas, pois:

[...] cada um de nós tem histórias de vida diferentes, onde foram construídos nossos limites à frustração, conceitos sobre o que é certo ou errado, qual a maneira mais eficaz de se agir diante de um conflito etc. Também, não podemos afirmar que existam comportamentos que sejam em si violentos (um tiro, por exemplo, não é uma violência quando acontece dentro da prática esportiva do tiro ao alvo). Devemos sempre analisá-los no contexto em que eles surgem e as conseqüências daí recorrentes. (OSÓRIO, 2000, p. 5)

Segundo esse autor, há estudos que:

[...] permitem esboçar traços caracterológicos que aparecem com freqüência em indivíduos considerados muito agressivos ou violentos. Tais indivíduos apresentam baixa auto-estima, alta vulnerabilidade à humilhação, inabilidade no auto-domínio e deficiente controle de seus impulsos e labilidade emocional. Estas características podem estar exacerbadas nesses indivíduos, mas aparecem com intensidade menor em todas as pessoas em algum momento de sua vida. (OSÓRIO, 2000, p. 5)

\section{Violência x conflitos}

Conflito pode ser definido da seguinte forma:

O conflito consiste em querer assumir posições que entram em oposição aos desejos do outro, que envolve uma luta pelo poder e que sua expressão pode ser explícita ou oculta atrás de uma posição ou discurso encobridor. (VEZZULLA apud OSÓRIO, 2000, p. 6)

Segundo Osório (2000), conflito tem, de imediato, uma conotação negativa, ou seja, um perigo eminente carente de defesa.

Nesse sentido:

Como todo os seres vivos, o homem procura preservar sua integridade psíquica e física. Essa integridade é construída ao longo da vida do indivíduo e inclui todas as suas posses (que vão desde os bens ate a imagem que ele faz de si mesmo de acordo com seus valores morais). É essa integridade que se vê em perigo quando se aproxima um conflito. Num assalto, por exemplo, se eu não entregar meu dinheiro, o assaltante pode me matar ameaçando minha integridade física. Mas pode ser também, que eu, nessa situação, me sinta impotente e ineficaz pelo fato de estar sendo assaltado, e neste caso o que está sendo ameaçado é minha integridade psíquica. A sensação de ameaça tem como chave o sentimento de invasão que geralmente sentimos, seja porque nossas ações e valores estão sendo questionados, seja porque nosso "corpo" (e aí podemos pensar que tudo que considero meu faz parte desse corpo - a casa em que vivo, o carro que tenho, as pessoas que gosto etc.) está em perigo. (OSÓRIO, 2000, p. 5)

Para esse autor, os conflitos podem ser causados por diversos fatores: invasão de espaço pessoal - privacidade, dificuldades na comunicação, pressão, frustração, tensão etc. Tudo isso pode gerar uma reação inesperada, ou seja, comportamentos agressivos e violentos.

Segundo Vezzulla (1998 apud OSÓRIO, 2000), quando o ser humano está em conflito, sente-se 
invadido e acredita estar correndo o risco de perder alguma coisa. Esse medo gera uma série de comportamentos agressivos. Por exemplo:

Quando, numa discussão, alguém duvida de minha palavra, eu posso me sentir extremamente ofendido e, ao invés de argumentar coerentemente com essa pessoa, começar a agredi-la verbalmente ou até mesmo partir para uma agressão física. O incômodo sentido pode ser tão grande que 'explodimos' numa tentativa de aliviar a tensão, mas o que acontece, na maioria das vezes, é a utilização de estratégias violentas por estarmos acostumados a elas, não sabermos resolver o conflito de outra maneira, ou ainda, não medirmos as consequências dos atos violentos. (OSÓRIO, 2000, p. 6)

Trata-se, então, de saber manejar o conflito, ou seja, ter domínio próprio. Esse domínio pode ser conseguido por intermédio do famoso conselho "conte até dez". Parece que não, mas funciona. A partir daí, por meio do diálogo, por exemplo, pode-se, "negociar com o outro". Essa é uma estratégia que pode barrar a violência, dando lugar à paz.

\section{Acrescenta o mesmo autor:}

Se as pessoas não sabem o que querem, nunca pararam para pensar a respeito de seus valores, sentimentos, não aprenderam ou não foram devidamente incentivadas a aprender estratégias não violentas para solucionar conflitos, ou não estão seguras de suas capacidades, conflitos podem surgir com muita frequência e, fatalmente, suas próprias questões particulares aparecerão dificultando a resolução deste. Cada um de nós pode se relacionar de uma maneira menos violenta, tornando-se mais consciente das reações diante de situações de conflito, ameaças e fortes emoções. Sabendo o que pode despertar nossa violência, podemos desenvolver habilidades para enfrentar os conflitos cotidianos, através de estratégias mais eficazes para resolvê-los. Além disso, quando estamos conscientes sobre as consequências de nossas ações, nos responsabilizamos por nossos atos, e podemos colocar em prática pequenas atitudes que interrompem cadeias de pequenas ações e atitudes agressivas, que poderiam levar a atos maiores de violência. (OSÓRIO, 2000, p. 6)

Violência e paz são temas complexos, que abrangem um vasto complexo de causas variáveis, como: psicológicas, sociais, econômicas, culturais etc. Nesse sentido, cabe aqui uma recomendação desse autor:

Não se faz ideia de tudo quanto se vai encontrar ao prospectar o império da violência; eis porque uma anatomia da guerra que se gabasse de ter descoberto três ou quatro grossos cordéis, que bastaria cortar para que as marionetes militares caíssem inertes no tabuado do palco, condenaria o pacifismo à superficialidade e à puerilidade. (R1COEUR, 1968, p. 227)

A discussão sobre violência e paz emerge, geralmente:

[...] após a experiência de algum fato de maior gravidade, como um crime hediondo ou uma tragédia comunitária. Neste contexto, sempre surge uma pesquisa sobre a pena de morte ou sobre a militarização do parelho policial. Criticar este viés emocional e desprender a discussão deste contexto é um dos primeiros passos a serem tomados, rumo a uma solução séria e racional para a questão. (GUIMARÃES, 2000, p. l)

Cabe lembrar que, de acordo com Ferreira (1986, p. 630), o termo "hediondo" pode constituir um ou mais dos seguintes adjetivos: "depravado, vicioso, sórdido, imundo, repelente, repulsivo, horrendo, sinistro, pavoroso e, medonho". Outro cuidado a ser tomado é o de não mistificar a violência como um ente, muitas vezes, "[...] os discursos sobre violência começam subjetivando-a, como se fosse uma entidade autônoma ou um princípio de ação, através de formulações 
tipo 'a violência cresce', 'a violência se alastra', etc." (GUIMARÃES, 2000, p. 2).

Nesse sentido, "[...] a violência não promove causas, nem a história, nem a revolução, nem o progresso, nem o retrocesso; mas pode servir para dramatizar queixas e trazê-las à atenção pública" (ARENDT, 2000, p. 58). Sob esse prisma, pode-se afirmar que as políticas públicas podem ganhar nova força sem a violência, pois:

A sociedade brasileira testemunha, atualmente, um processo de banalização da violência. $\bigcirc$ 'tudo' é violência pode conduzir a uma consideração de que nada é violência ou que apenas o crime seja violência, provocando uma unilateralização do conceito e o desconhecimento de outras formas de violência, tais como a psicológica ou simbólica. Além disso, os discursos sobre violência na educação procedem a mixagens semânticas, confundindo, por exemplo, violência com agressividade ou opondo paz com conflito. A psicologia, hoje tende a reconhecer a agressividade como uma energia humana necessária e que, de acordo com os condicionamentos de toda ordem, pode ser transformada em violência. Da mesma forma, os conflitos e as lutas são reconhecidos como constitutivos do processo humano, não se opondo em si à paz, mas conforme o modo como são organizados, violentos ou não-violentos. (GUIMARÃES, 2000, p. 3).

Segundo esse autor, é preciso compreender a violência como um fato humano e um atributo da sociedade:

Não existe em forma substantiva, mas sempre adjetiva como característica e expressão das relações humanas e sociais. Muitos discursos sobre a violência insistem tratá-la como uma doença ou como uma epidemia ou, então, associá-la como força presente na natureza. Nada é mais perigoso do que querer interpretar fatos sociais em termos biológicos. Paz e violência não são fenômenos naturais ou manifestações do processo vital, mas pertencem à esfera das relações humanas e sociais, e como tais devem ser tratados. Aqui, a precisão conceitual pode nos ajudar, no sentido de distinguir força, propriedade na natureza, de violência, atributo social. Como fato da sociedade, a violência está com relação à forma como que se dão os arranjos sociais. A violência não é uma fatalidade inexorável, mas colocada pelos humanos, portanto, pode ser retirada e trabalhada pelos mesmos humanos que a construíram. (GUIMARÃES, 2000, p. 4)

Para esse autor, a possibilidade da paz funda-se na habilidade humana para agir em "concerto", constituindo-se em uma das mais decisivas experiências humanas. Arendt (2000) denomina isso de poder, não como prerrogativa do Estado - ou dos grupos dominantes -, mas como condição da própria humanidade, pois o que está em jogo não são paradigmas que determinam as relações sociais. Nesse sentido, de acordo com Santos (2000), o que ocorre é um processo de transição paradigmática, mudando os padrões e critérios regulatórios. Nesse processo:

[...] o pensamento crítico, para ser eficaz, tem de assumir uma posição paradigmá tica para, partindo de uma critica radical dos paradigmas dominantes, desenhar os primeiros traços dos horizontes emancipatórios em que eventualmente se anuncia o paradigma emergente. (SANTOS, 2000, p. 16)

Assim sendo, percebe-se a importância de se detectar, coletivamente, os processos culturais de produção da violência.

Não apenas vivemos numa sociedade violenta, mas, sobretudo, numa cultura violenta, produzida e, ao mesmo tempo, difundida, por inúmeras instâncias da sociedade: os meios de comunicação, a escola, as famílias, as instituições religiosas, os partidos políticos, os clubes, os sindicatos, etc. Como disse poeticamente Caetano Veloso, "nossos podres poderes fazem a gente pensar que matar e morrer 
sejam coisas naturais". Há um currículo oculto, baseado no paradigma bélico, que nos educa para a violência e que, quaisquer políticas públicas que se pretendem eficazes, não podem desconhecer e precisam atuar. (GUIMARÃES, 2000, p. 4)

A sociedade brasileira já se manifesta mais efetivamente contra a violência em prol da construção de uma sociedade verdadeiramente pacifista e uma cultura de paz, atentando para a dimensão sanativa, de cuidar e atender às vítimas da violência, e de uma dimensão preventiva, privilegiando, especialmente, o caminho educativo (GUIMARÃES, 2000).

As medidas para o fim da violência e implementação da paz terão alcance muito reduzido se permanecerem no campo restrito da resposta à violência e à guerra. Faz- se necessário, para se conseguir uma solução eficaz, criar pólos positivos de nãoviolência e paz. Há mais de 50 anos já nos lembrava Ghandi: "a humanidade somente acabará com a violência através da não-violência". Somente a não-violência é a alternativa e a superação da violência, uma vez que ela se situa no âmbito totalmente exterior à violência. (GUIMARÃES, 2000, p. 5)

Segundo esse autor, a modernidade neoliberal se apegou ao conceito romano de paz, associando-o às noções de segurança e de serenidade pessoal. Assim, novos paradigmas devem ser resgatados, como:

[...] a compreensão filosófica moderna de paz como pacto e consenso ou a noção judaico-cristã de paz como justiça. A noção comumente admitida procede a uma privatização do conceito, tirando- the suas dimensões coletivas e políticas. (GUIMARÃES, 2000, p. 5)

Sob esse prisma:

[...] ao discutir propostas pedagógicas para culturas de paz algumas idéias desde a América Latina, chama a atenção para a fetichização do termo paz e aponta a necessidade de pensá-la mais como uma construção do que um estado, mais como pluralidade do que como unicidade (em vista das superações do etnocentrismo): mais como algo relacionado ao nosso cotidiano do que uma ideia abstrata. (BRANDÃO, 1995, p. 47)

Soluções plausiveis seriam: o aumento do aparelho repressivo, a instituição da pena de morte, o fortalecimento do aparato bélico. Nesse sentido, corrobora-se com esta afirmação:

\begin{abstract}
É a compreensão romana de paz, baseada na imposição da força "si vis pacem para bellum", isto é, se queres a paz, prepara-te para a guerra. No entanto, a humanidade não avançará na prática dos direitos humanos por decreto, ou por leis ou, ainda, fortalecendo o aparelho repressivo. Devemos evitar medidas paliativas ou que dêem a falsa impressão de avanço. O fim da impunidade é, certamente, passo fundamental para avançarmos na direção de menos violência. (GUIMARÃES, 2000, p. 7)
\end{abstract}

Mas acredita-se que isso não bastaria para garantir uma sociedade livre, é preciso partir do princípio racional que somente por intermédio da via educativa haverá mudanças de posicionamentos.

O mundo é um campo minado e pervertido de graça e de pecado. Na intuição séria e profunda de São Francisco de Assis, encontramos uma oração na qual o caminho da paz se abre no momento em que reforçamos o amor onde há ódio; o perdão onde ocorre a ofensa... O polo negativo não é negado nem recalcado. É assumido, mas submetido à lógica do polo positivo. O efeito dessa estratégia sapiencial é a paz possível aos seres contraditórios que somos e a essa terra conturbada. Só meios pacíficos vividos por mentes pacíficas podem produzir a paz.

Antes de passar para o próximo capítulo, onde se aprofunda a temática da violência no ambiente escolar, faz-se necessária uma reflexão sobre a oração abaixo citada: 
Senhor, fazei-me instrumento de vossa paz. Onde houver ódio que eu leve o amor. Onde houver ofensa, que eu leve o perdão; Onde houver discórdia, que eu leve a união; Onde houver dúvida, que eu leve a fé; Onde houver erro, que eu leve a verdade; Onde houver desespero, que eu leve a esperança;

Onde houver tristeza, que eu leve a alegria: Onde houver trevas, que eu leve a luz.

Ó Mestre, fazei que eu procure mais consolar que ser consolado;

Compreender que ser compreendido; Amar que ser amado.

Pois e dando que se recebe,

É perdoando que se é perdoado,

E é morrendo que se vive para a vida eterna. Amém.

\section{A Violência no Ambiente Escolar}

Posto a violência em termos gerais, segue a posição dela no ambiente escolar, conforme teóricos pertinentes.

\section{Fatores de Risco}

Na atualidade, um dos temas que vêm despertando cada vez mais o interesse de profissionais das áreas de educação e saúde em todo o mundo é, sem dúvida, a violência escolar, ou seja, comportamentos agressivos e antissociais nas instituições escolares. Este não é um problema recente, nem de um fenômeno desconhecido. Existe desde que a instituição escolar passou a existir e se instala nos locais de aprendizagem, onde os alunos deveriam adquirir valores e normas para construírem sua personalidade e identidade. Por essa razão toma-se relevante a preocupação com as questões relacionadas com a violência dentro desse ambiente onde se processa a construção de personalidades para a vida toda de crianças/adolescentes.

Conforme Lopes Neto (2005), a existência da violência nas escolas é um problema social complexo e delicado, classificado como grave.
A violência escolar diz respeito a todos os comportamentos agressivos e anti-sociais, incluindo os conflitos interpessoais, danos ao patrimônio, atos criminosos, etc. muitas dessas situações dependem de fatores externos, cujas intervenções podem estar além da competência e capacidade das entidades de ensino e de seus funcionários. Porém, para um sem número delas, a solução possível pode ser obtida no próprio ambiente escolar. (LOPES NETO, 2005, p. 165)

Segundo esse autor, a violência se traduz em uma forma de conduta com a intenção de ferir alguém, tanto a nível psicológico quanto fisicamente, como citado anteriormente. Isso aponta para a intencionalidade do ato agressivo, quando o indivíduo procura obter algo, coagir alguém para poder demonstrar a sua força e o seu poder.

Frisou-se o comentário no sentido de mostrar que não é fácil tratar do tema violência almejando o antídoto "paz". Nesse sentido:

\begin{abstract}
[...] diante da dificuldade de conceituar violência, é preciso estar bem atento para vencer as tentações, sempre presentes, do simplismo ou do reducionismo como, por exemplo, associar violência com falta de segurança ou tentar explicar o fato por apenas uma variável, como a pobreza. (GUIMARÃES, 2006, p. 3)
\end{abstract}

Assim sendo, frisando o comentado na introdução, a violência é um constrangimento exercido sobre alguma pessoa para obrigá-la a fazer ou deixar de fazer um ato qualquer. Portanto, a violência subentende uma disputa de poder. Aquele que melhor usar as técnicas de coação terá o poder sobre o outro. Assim, se conclui que a violência existe desde que o homem se organizou em sociedade. Então, ela não se justifica como fenômeno dos dias "tecnológicos" de hoje. Sempre existiu, provável e lamentavelmente, até como uma forma de sobrevivência dos seres vivos: a lei do mais forte. Desta forma, a violência deixou de ser uma con- 
dição de sobrevivência para se tomar um meio de obter o poder, um meio de dominar o outro. E esse jogo - desnecessário - de poder está presente em todas as relações sociais: patrões e empregados, marido e mulher, pais e filhos, professores e alunos, gangues, traficantes e traficantes, corruptos e corruptores, e assim por diante. Entende-se que as causas da violência se resumem em obter o poder: físico, psicológico, econômico ou social sobre uma pessoa, um grupo ou uma nação. Suas consequências são a perda de valores do homem civilizado: a igualdade, a fraternidade e a liberdade. Essa perda gera revolta e insatisfação, dois caminhos que geram mais violência, formando um ciclo vicioso sem fim (GUIMARÃES, 1996).

\section{A Violência na Escola}

Menin e Zandonato (2000) expõem que a violência na escola encontra-se em relações conflituosas e danosas entre professores e alunos e dos alunos entre si. Essa violência, segundo as autoras, seria resultado do reflexo e da reprodução de outras violências que as cercam: violência na sociedade, violência na escola e a do próprio indivíduo advinda de origem diversas.

A forma extrema do poder é todos contra
um e a forma extrema da violência é um
contra todos. [...] a violência não emerge
do poder, pois quem o tem de forma se-
gura, não necessita usar de violência [...]
a violência sempre pode destruir o poder.
(ARENDT, 2000, p. 35)

Essa autora entende que a relação entre poder e violência não pode ser uma regra na compreensão da origem da violência, pois nem toda ação violenta é advinda da falta de poder. Em alguns casos, o poder que é conferido ao indivíduo pelo lugar que ocupa é usado como forma de controle. Embora a mesma autora exponha que a falta do poder gera a necessidade de controle pela coação, entendimento com o que se concorda; não se pode, entretanto, ser condizente em dizer que todos que têm o poder usam de violência.
Há casos de professores que têm comportamento violento mesmo tendo o domínio do poder, seja ele institucionalizado pelo lugar que ocupa ou pela competência no "domínio" de situações. Assim, fica claro que o poder de um indivíduo não é garantia de ações justas, mesmo sendo esse poder baseado em competência e não em lugares institucionalizados. Esse é um dos aspectos enfatizados por Arendt (2000, p. 43) a respeito da relação entre poder e violência.

\footnotetext{
Tem sido bastante discutido que a impotência gera violência e, psicologicamente, isto é verdadeiro, ao menos para pessoas que possuam vigor natural, moral ou físico. Politicamente, o ponto é o de que com a perda do poder torna-se uma tentação substituí-lo pela violência.
}

Reitera-se que Arendt (2000) possui fundamento em suas definições, diferenciações e até relações entre poder e violência. O que causa estranheza é a determinação de um fenômeno sobre outro, de forma a não haver possibilidades de alterações ou outras interferências neles.

Candau, Lucinda e Nascimento (1999) discutem algumas relações entre violência e sociedade e entre violência e escola sobre a perspectiva de diferentes autores que relacionam violência com a tendência à destruição do outro, ao desrespeito e à negação do outro em três planos: no plano físico, no plano psicológico e no plano ético.

Nessa mesma perspectiva, Macedo (1996) defende que violência é toda e qualquer ação que utiliza outrem apenas como meio e não como fim em si mesmo. Dessa forma, não só a violência física, mas a intimidação, a humilhacão e a coação são, também, meios violentos presentes nas relações interpessoais.

Visões mais restritas, porém, também são expostas por Candau, Lucinda e Nascimento (1999), como é o caso explícito no dicionário marxista de Bottomore (1998), que relaciona violência somente ao prejuízo físico do indivíduo ou do grupo.

Para os marxistas, portanto, a violência seria pontual, pois se encontraria somente nas relações em que se estabelecem agressões físicas. 
Cabe aqui uma observação sobre a raiz da palavra agressividade:

[...] vem do latim: 'ad+gradior' onde 'ad' significa "para frente" e "gradior", "movimento". Pode-se afirmar que a agressividade é "um movimento em direção de", caracterizada pelo componente ativo, pela tendência a ação. Desta maneira, a agressividade faz parte de todo o ser vivo e é fundamental à sobrevivência, pois é aquilo que faz agir. Porém, como as ações podem ter propósitos e conseqüências destrutivas (no sentido de não preservarem a vida e o bem estar individual e social), alguns autores propõem que, nestes casos, o termo agressão seja utilizado, e que, quando as ações tenham propósitos e conseqüências construtivas utilize- se o termo agressividade (quando forem ações que preservem a vida e o bem estar individual e social). (OSÓRIO, 2000. p. 2)

Candau, Lucinda e Nascimento (1999) expõem a visão de outros autores que relacionam a violência a fatores como a organização social, pela existência das desigualdades sociais e, principalmente, pela forma como são estabelecidas as relações de poder que intensificam as diferenças. Outras discussões a respeito, no entendimento desses autores, apontam para a cultura da violência, desenvolvida e exposta pelos meios de comunicação de massa, através da banalização desse fenômeno, ou seja, através da naturalização de comportamentos violentos como forma de legalização deles, além de disseminar o sentimento de insegurança nas relações interpessoais.

Aquino (1996) discute um aspecto específico da violência, a violência institucional. Há três perspectivas de violência institucional no caso da escola:

- A violência dos poderes instituídos ou utilitária que neutraliza as diferenças individuais e objetiva a homogeneização;

- A violência anômica, observada nas reacões brutais, como depredação e agressividade entre alunos;
- A violência banal, caracterizada pela resistência passiva através de comportamentos de ironias, chacotas etc.

Analisando sobre esses aspectos, a escola realmente reproduziria, enquanto instituição, as desigualdades sociais de diversas maneiras, como pode ser constatado quando alunos com deficiências, as mais diversas, são discriminados. Alunos que são estigmatizados por dificuldades de aprendizagem, por sua cor, por seu nível econômico, por sua origem humilde etc.

A violência da escola, nesse caso, aconteceria através do currículo oculto, através da intimidação pela nota, pela reprovação ou até pela humilhação psíquica/moral.

Ao enfocar a violência presente nos meios de vida pública, Arendt (2000) leva o leitor a uma transposição das situações de violência às de indisciplina, de acordo com o enfoque dado pela psicologia institucional, ao afirmar que, quanto maior é a burocratização da vida pública, maior será a atração pela violência.

Essa posição pode ser associada ao enfoque dado por Aquino (1996) ao discutir a cristalização das práticas escolares. Ao associar essa ideia à de Arendt (2000), tem-se que a indisciplina pode ser entendida como uma reação à burocratização que é consolidada nas maioria das práticas escolares.

Piaget (1994) expõe que os pais têm muita responsabilidade sobre as dificuldades e/ou problemas apresentados pelos filhos e que, em investigações ou tratamentos, é quase sempre presente em crianças ou adultos em situações problemáticas as lembranças familiares negativas.

[...] é impossível fazer a psicanálise de um adolescente ou de um adulto sem que no decorrer da anamnese espontânea, sempre tão cheia de interesse, à qual se entrega o indivíduo, as recordações mais nítidas relativas às faltas pedagógicas dos pais não reapareçam em grande número. (PIAGET, 1994, p. 152)

Com isso, não se está aqui apontando que, para Piaget (idem), a responsabilidade de 
educação das crianças seja integralmente dos pais, mas que a atuação destes é determinante na formação do indivíduo.

Aquino (1996, p. 46) também questiona sobre a responsabilidade dos pais e da escola, sugerindo que "[...] hoje há uma confusão de papéis quando a escola coloca-se como instituição que deve moralizar seus usuários (no caso, os alunos), através da normatização atitudinal".

Mesmo defendendo que a escola deva lidar com o indivíduo como um todo, esse autor não defende que ela ocupe o lugar integral da família na formação do indivíduo, pois essa determinação sobre limites da ação e papel das famílias e da escola não está bem definida e, além disso, mesmo que as famílias não estejam cumprindo seu papel, o que não entra aqui em discussão, a escola deve cumprir o seu.

Portanto, indisciplina, violência e preconceito podem ser atribuídos a fatores externos à escola e/ou a fatores que envolvem a conduta do professor, sua prática pedagógica e até práticas da própria escola que podem ser excludentes. É preciso estar ciente desses aspectos envolvidos e desenvolvidos na escola, como a relação professor-aluno, as dificuldades cognitivas encontradas pelos alunos geradas por diversos fatores, como a possibilidade de o cotidiano escolar ser permeado por um currículo oculto, entre outros. Assim sendo, fica claro que a violência escolar é advinda de vários fatores. Desta forma, não envolve somente características provenientes da escola e em suas relações entre aluno-professor, mas também aquelas encontradas fora da escola como problemas sociais, por exemplo, sobrevivência precária e baixa qualidade de vida, além de conflitos nas relações familiares.

Para Aquino (1996), quase sempre se associa indisciplina com violência, dessa forma, há dois referenciais amplos de análise: um que analisa a indisciplina sob o aspecto da perspectiva institucional e outro, a perspectiva da moralidade relacionada com a violência. A moralidade deve ser investigada justamente porque muitos professores parecem localizar a violência e indisciplina como fatores pura e simplesmente causados pela falta de educação moral que deveria ter sido feita pelas famílias. Mas é facilmente perceptível que a violência e o preconceito tenham diferentes fatores causais, mesmo internos à escola.

Cabe aqui ressaltar o preconceito racial:

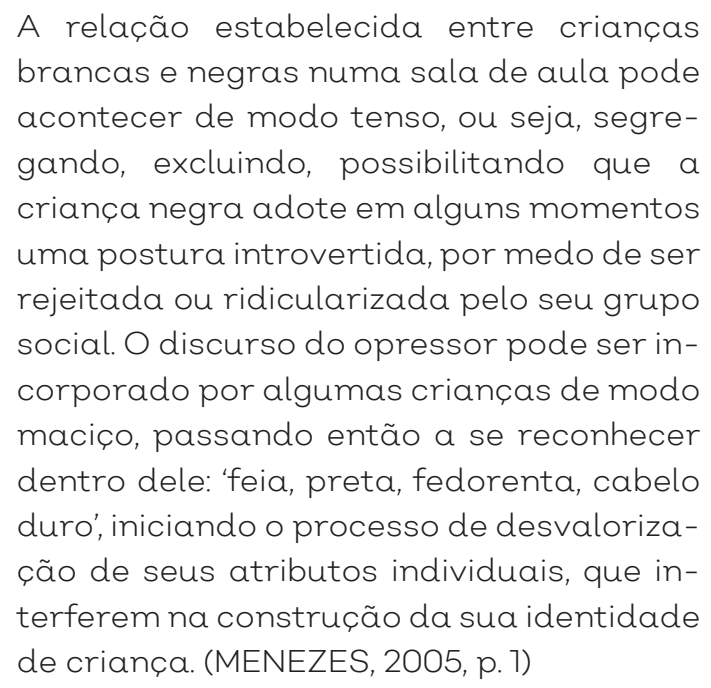

Segundo essa autora, a escola é responsável pelo processo de socialização infantil, pois é, também, o primeiro espaço de vivência das tensões raciais.

O preconceito pode desencadear a violência, assim sendo, considerou-se necessário e interessante levantar maiores esclarecimentos sobre o preconceito na escola no próximo tópico.

\section{Preconceito na Escola}

A proposta da inclusão educativa representa uma aspiração que vem sendo delineada desde as últimas décadas do século passado com o intento de identificar e suprimir todas as barreiras, quer sejam arquitetônicas, de comunicação, atitudinais ou instrumentais, que dificultam não só a entrada como também a continuação do sujeito na escola. Assim, embora haja inúmeras definições para o que vem a ser o "paradigma da inclusão", ele é usualmente entendido como a participação de qualquer indivíduo, sem exceção, na vida acadêmica, considerando que deve ser desenvolvido por meio de um trabalho 
pedagógico extensivo a todos, sem trazer no seu bojo nenhuma forma de discriminação. A esse respeito, Mantoan (1998) alerta que o objetivo é garantir a equidade de oportunidades, aceitar a diversidade, compreender e trabalhar a heterogeneidade, de maneira que todas as pessoas sintam-se acolhidas, ao tempo que lhes possibilite oportunidades para que se desenvolvam.

No entanto, o que ainda constatamos é que, nas escolas e na vida, a criança com alguma deficiência, seja ela da área motora, como dificuldade ou impossibilidade de andar, ou de segurar um objeto, seja da área da percepção dificuldade de ouvir ou de ver ou intelectiva - defasagem, por alguma razão, em relação aos seus companheiros da mesma idade - tem problemas que outras não têm, sofrendo, por esse motivo, grande preconceito no ambiente escolar, na comunidade e na sociedade (ROSENFELD, 2005).

Como ela não possui todos os instrumentos necessários para o processo de aprendizagem que gera um desenvolvimento normal, a sua interação com as pessoas com quem convive fica prejudicada. É preciso dar-se conta desta realidade e agir no sentido de ajudar a criança, estimulando-a a superar os obstáculos que ela enfrenta a toda hora. Uma grande sensibilidade é necessária para saber como ajudá-la na medida justa e hora certa, e não mais do que isto, para que a criança experimente a sensação insubstituível de vitória pessoal, por ter resolvido por seu próprio esforço uma situação que para ela representava um difícil problema. (ROSENFELD, 2005, p. 2)

Segundo Portela (2011, p. 1.259), essa compreensão é resultante do modelo reducionista de escola que, diga-se de passagem, esteve por muito tempo vigente, e na qual o aluno tem sido exclusivamente o mesmo, sendo assentado pelo padrão de referência que procura manter a "normalidade" do mundo a partir de uma coerência fundamentada na igualdade, a qual é garantida pelos princípios liberais que têm como meta tratar o aluno de forma homogênea e, com isso, justifica-se a discriminação e a exclusão.
De acordo com Gil (1997), há muitas maneiras de conceituar quem pode ser classificado como pessoa com deficiência ou que possui características consideradas não normais; esses conceitos mudaram ao longo da história, assim como as palavras utilizadas para exprimi-los. Termos como: retardado, "doentinho", aleijado, surdo-mudo, surdinho, mudinho, excepcional, mongoloide, débil mental, lento, loiro(a)-aguado(a) - para indivíduos loiros de pele bem clara-, baleia fora d'água - para crianças de peso elevado-, e outros não são mais admitidos, atualmente, pois carregam muitos preconceitos. As pessoas, ao passarem pela análise crítica dos critérios sociais, os quais impõem a reprodução e a preservação de um espaço social baseado na homogeneidade e em códigos de rendimento e eficiência, buscam marginalizar e segregar quem não acompanha as capacidades ditas "normais", como uma tentativa de colocar a pessoa numa condição diferenciada, justificando, então, sua exclusão social (PORTELA, 2009, p. 1.260).

Por outro lado, na escala das habilidades intelectuais encontram-se as pessoas que são consideradas superdotadas ou com altas habilidades, que se caracterizam por um notável desempenho e elevada potencialidade em qualquer dos seguintes aspectos, isolados ou combinados (GARDNER, 1995).

Nem sempre a comunidade escolar está preparada para lidar com 'diferenças' e não sabe o que fazer. Isso cria um desconforto na interação social. $\bigcirc$ preconceito faz parte da natureza humana, desde o início dos tempos. O homem desconfia e tem medo de tudo o que é diferente dele mesmo. $O$ 'outro' inspira receio, temor, insegurança; daí para adotar atitudes defensivas e de ataque é um passo. Esses sentimentos eram importantes no tempo das cavernas, quando os homens eram poucos e lutavam bravamente para sobreviver em um ambiente hostil. Infelizmente, persistem até hoje, nas lutas entre católicos e protestantes, árabes e judeus, muçulmanos e cristãos, brancos e negros. (ROSENFELD, 2005, p. 3) 
Segundo essa autora, os critérios dessa "classificação" dependem dos seguintes comportamentos: a qualidade da expressão, o modo de olhar, de comer, de andar, de vestir, o senso de humor, entre outros.

Muitas vezes, a segregação começa a partir da colocação de 'rótulos' ou de 'etiquetas' nas pessoas com deficiência, do tipo 'não vai aprender a ler', 'não pode fazer tal movimento' e outros. Estas 'etiquetas' têm consequências sobre a forma como estas pessoas são aceitas pela sociedade e não permitem que a própria pessoa se exprima e mostre do que é capaz. (ROSENFELD, 2005, p. 3-4)

\section{Para essa autora:}

A partir do reconhecimento e da aceitação de nossos preconceitos e desconfianças, estamos aptos a mudar nosso comportamento e a aceitar que o objeto destes sentimentos é uma pessoa como nós, ou seja, começaremos a identificar os pontos comuns entre nós e não mais a acentuar as diferenças. (ROSENFELD, 2005, p. 5)

Assim, pode-se, então, identificar que a diversidade dos seres humanos indica riqueza de situações e possibilidade de intercâmbio de vivências e de aprendizagem. Os diferentes ritmos, comportamentos, experiências, trajetórias pessoais, contextos familiares, valores e níveis de conhecimento de cada criança (e do professor) imprimem ao cotidiano escolar a possibilidade de troca de repertórios, de visão de mundo, bem como os confrontos e a ajuda mútua, e a consequente ampliação das capacidades individuais.

Deve-se suscitar a necessidade de se ressignificar a escola, de repensá-la, tendo em vista a necessidade de deixar de ser "escola de programas" para ser uma "escola de sujeitos" (MORIN, 2000). Nessa perspectiva, trata-se de perceber que a escola deve pensar em formar pessoas para serem solidárias, livres e capazes de se articularem consigo mesmas, com o outro e com o meio.

Segue a versão de Popkcwitz e Lindblad (1997, p. 4-6) sobre bullying aqui sintetizada: o termo bullying tem origem na palavra inglesa bully que significa "valentão, brigão". Como verbo, significa ameaçar, amedrontar, tiranizar, oprimir, intimidar, maltratar. O primeiro a relacionar a palavra ao fenômeno foi Dan Olweus, professor da Universidade da Noruega. Ao pesquisar as tendências suicidas entre adolescentes, Olweus descobriu que a maioria desses jovens tinha sofrido algum tipo de ameaça e que, portanto, bullying era um mal a combater. Ainda não existe termo equivalente em português, mas alguns psicólogos estudiosos do assunto o denominam "violência moral", "vitimização" ou "maltrato entre pares", uma vez que se trata de um fenômeno de grupo, em que a agressão acontece entre iguais - no caso, estudantes alunos, crianças ou adolescentes. As agressões se dão dentro de uma relação desigual de poder e podem ser provocadas por uma ou mais crianças ou adolescentes contra outro ou outros. Como exemplos de comportamentos provenientes do bullying destacam-se: colocar apelidos, intimidar, chamar atenção para um defeito, excluir, humilhar.

O bullying é um problema social mundial e aparece em qualquer escola. Recentemente, também surgiu o bullying virtual ou cyber bullying, em que meninos e meninas - crianças ou adolescentes - usam meios da internet como orkut MSN e blogs para agredirem colegas ou uma pessoa qualquer.

Já para Fante (2005, p. 12-45), entendimento também aqui sintetizado, o bullying é um conceito específico e muito bem definido, uma vez que não se deixa confundir com outras formas de violência. Isso se justifica pelo fato de apresentar características próprias, dentre elas, talvez a mais grave seja a propriedade de causar "traumas" ao psiquismo de suas vítimas e envolvidos. Possui ainda a propriedade de ser reconhecido em vários outros contextos, além do escolar: nas famílias, nas forças armadas, nos locais de trabalho - o "famoso" assédio 
moral -, nos asilos de idosos, nas prisões, nos condomínios residenciais, enfim, onde existem relações interpessoais.

Para estudiosos do comportamento, bullying entre escolares identificam e classificam assim os tipos de papéis sociais desempenhados pelos seus protagonistas: "vítima típica", como aquele que serve de "bode expiatório" para um grupo; "vítima provocadora", como aquele que provoca determinadas reações contra as quais não possui habilidades para lidar; "vítima agressora", como aquele que reproduz os maus-tratos sofridos; "agressor", aquele que vitimiza os mais fracos; "espectador", aquele que presencia os maus-tratos, porém não o sofre diretamente nem o pratica, mas que se expõe e reage inconscientemente a sua estimulação psicossocial.

Segundo algumas correntes teóricas, as causas desse tipo de comportamento abusivo são inúmeras e variadas. Deve-se à carência afetiva, à ausência de limites e ao modo de afirmação de poder e de autoridade dos pais sobre os filhos, por meio de "práticas educativas" que incluem maus-tratos físicos e explosões emocionais violentas. O portador dessa síndrome possui necessidade de dominar, de subjugar e de impor sua autoridade sobre outrem, mediante coação: necessidade de aceitação e de pertencimento a um grupo; de autoafirmação, de chamar a atenção para si. Possui, ainda, a inabilidade de expressar seus sentimentos mais íntimos, de se colocar no lugar do outro e de perceber suas dores e sentimentos. Essa síndrome apresenta rica sintomatologia: irritabilidade, agressividade, impulsividade, intolerância, tensão, explosões emocionais, raiva reprimida, depressão, sintomas psicossomáticos etc. É oriunda do modelo educativo predominante introjetado pela criança na primeira infância. Sendo repetidamente exposta a estímulos agressivos, aversivos ao seu psiquismo, a criança os introjeta inconscientemente ao seu repertório comportamental e transforma-se posteriormente em uma dinâmica psíquica "mandante" de suas ações e reações.

Dessa forma, tornar-se-á predisposta a reproduzir a agressividade sofrida ou a repri- mi- la, comprometendo, assim, seu processo de desenvolvimento social.

As consequências para as "vítimas" desse fenômeno são graves e abrangentes, promovendo no âmbito escolar o desinteresse pela escola, o deficit de concentração e aprendizagem, a queda do rendimento, o absentismo e a evasão escolar. No âmbito da saúde física e emocional, baixa na resistência imunológica e autoestima, sintomas psicossomáticos, transtornos psicológicos, depressão e suicídio. Para os "agressores", ocorre o distanciamento e a falta de adaptação aos objetivos escolares, a supervalorização da violência como forma de obtenção de poder, o desenvolvimento de habilidades para futuras condutas delituosas, além da projeção de condutas violentas na vida adulta. Aos "espectadores", a maioria dos alunos, pode ocorrer insegurança, ansiedade, medo e estresse, comprometendo o seu processo socioeducacional.

Esse fenômeno envolve e vitimiza a criança, na tenra idade escolar, tomando-a refém de ansiedade e de emoções, que interferem negativamente nos seus processos de aprendizagem devido à excessiva mobilização de emoções de medo, de angústia e de raiva reprimida. A forte carga emocional traumática da experiência vivenciada, registrada em seus arquivos de memória, poderá aprisionar sua mente a construções inconscientes de cadeias de pensamentos desorganizados, que interferirão no desenvolvimento da sua autopercepção e autoestima, comprometendo sua capacidade de autossuperação na vida. Dependendo do grau de sofrimento vivido pela criança, ela poderá sentir-se ancorada a construções inconscientes de pensamentos de vingança e de suicídio, ou manifestar determinados tipos de comportamentos agressivos ou violentos, prejudiciais a si mesma e à sociedade, isto se não houver intervenção diagnóstica, preventiva e psicoterápica, além de esforços interdisciplinares conjugados, por toda a comunidade escolar. Nesse sentido, podem-se citar as recentes tragédias ocorridas em escolas, por exemplo, Columbine (EUA); Taiuva (SP); Remanso (BA), Carmen de Patagones (ARG) e Red Lake (EUA). 
Essa forma de violência é de difícil identificação por parte dos familiares e da escola, uma vez que a "vítima" teme denunciar os seus agressores, por medo de sofrer represálias e por vergonha de admitir que está apanhando ou passando por situações humilhantes na escola, ou, ainda, por acreditar que não the darão crédito. Sua denúncia ecoaria como uma confissão de fraqueza ou impotência de defesa. Os "agressores" se valem da "lei do silêncio" e do terror que impõem às suas "vítimas", bem como do receio dos "espectadores", que temem se transformarem na "próxima vítima".

\section{Escola e Educação}

Este capítulo apresenta as perspectivas da educação no processo "paz e não violência" e sugestões de teóricos em prol da erradicação da violência e uma cultura de paz.

\section{Famílias e Escola}

Na busca de novos paradigmas, é como um clamor a necessidade de uma interação consistente entre a família e a escola.

\section{Aspecto Socioafetivo}

Segundo Lopes Neto (2005), a educação integral não depende unicamente do desempenho das escolas e dos alunos. A participação das famílias é fundamental, influenciando decisivamente no processo.

A família configura-se como uma instituição socializadora, como célula básica da sociedade, cuja importância é decisiva no desenvolvimento do sujeito. Para Alves (2001), a família é o agente principal de socialização primária, a qual se refere à internalização de determinado sistema simbólico que junta os aspectos principais da identidade dos indivíduos. Tal sistema funciona como direção para a inclusão da criança num universo social mais amplo. Assim, a família se constitui como um dos lugares-chave de socialização, de educação e cuidado das novas gerações. Por conseguinte, é fundamental reco- nhecer a família como um fator potencialmente ativo e não só complementar das ações sociais. Logo, ela oferece uma contribuição significativa para o bem-estar da sociedade e para a qualidade de vida das pessoas.

Como contexto cultural e de práticas educativas, a família ocupa um lugar privilegiado por estar imbuída de sentimentos e afetos na transmissão de elementos para a formação, isto é, na transmissão dos padrões de moral e convivência social que influenciam a personalidade do indivíduo.

Proprietária de uma característica não comum aos outros tipos de relações sociais, a família possibilita a realização de vínculos filiais expressos em relações afetivas e emocionais entre seus membros, difíceis de se encontrar em outros ambientes sociais (PORTELA, 2009), pois o ser humano, ao nascer, já se encontra integrado a uma família específica, com características próprias, pertencente a determinada cultura e ocupando uma posição socioeconômica definida dentro de um certo grupo cultural. Ainda mais, ele já nasce com um lugar de certa forma predeterminado dentro do grupo familiar.

Por isso, é preciso estreitar o laço entre educadores e famílias, promovendo diversas atividades que favoreçam a troca de informações, a abertura para o diálogo, a sugestão de propostas e o apoio mútuo. Assim, os pais devem acompanhar e atuar mais ativamente no progresso de seus filhos, tendo a oportunidade de conhecer melhor o cotidiano da sala de aula e a riqueza de projetos e atividades que compõem a proposta educativa da escola. Palestras e reuniões de pais, entre outros momentos, devem ser sempre pautados nos principais assuntos da atualidade - limites, drogas, violência, bullying, mídia etc. Essas ocasiões especiais servem, antes de tudo, a um grande propósito: o fortalecimento dos vínculos visando ao desenvolvimento cognitivo, cidadão e socioafetivo dos alunos.

O envolvimento dos pais com a escola vem sendo considerado, atualmente, como um elemento importante para o êxito escolar dos filhos e 
para o desempenho satisfatório das escolas, por isso essa temática vem sendo tratada por estudiosos com uma significativa e especial atenção.

Assim, conforme o que observaram Bhering e Siraj-Blatchford (1999, p. 192):

[...] o envolvimento de pais não só contribui com todo o processo escolar (tudo o que isso implica) como também contribui para uma melhoria dos ambientes familiares (no sentido de provocar uma maior compreensão do processo de crescimento e, portanto, da aprendizagem das crianças) e eventualmente poderá influenciar positivamente o curso do desenvolvimento das crianças, como o rendimento escolar.

Ainda conforme Lopes Neto (2005), há uma estreita relação entre os alunos violentos e famílias que favorecem comportamentos como o desrespeito, a discriminação, pois essas crianças já vêm com uma bagagem de ensinamentos das famílias. E o aluno que é violento geralmente vem de famílias que têm a violência como forma de posição de poder. Também há a questão das famílias que têm uma relação de afeto muito pobre. Essas crianças vivem em um ambiente onde não há uma troca de afeto muito grande entre os membros da família. Obviamente, não conseguem desenvolver esse afeto no ambiente escolar com os colegas. Assim, encontram-se em posição arredia, de pouco sentimento e amizade, pouca habilidade para desenvolver amizade. E a criança que sofre a violência muitas vezes é introvertida, muito tímida, pouco estimulada na família, e quase sempre é o "bode expiatório" da família. É aquela criança que, sistematicamente, ouve dos pais que, desde que ela nasceu, a vida deles é um inferno, que ela só dá problema, conveniente.

Assim, ela vem para a escola com uma autoestima muito abalada, sem habilidade para exercer uma troca ou até de se colocar dentro do grupo de uma forma mais amigável. De acordo com Lopes Neto (2005), os motivos que levam a esse tipo de violência são extremamente variados e estão relacionados com as experiências que cada aluno tem em sua família e/ou comunidade:

Famílias desestruturadas com relações afetivas de baixa qualidade, em que a violência doméstica é real ou em que a crianca representa o papel de bode expiatório para todas as dificuldades e mazelas são as fontes mais comuns [...]. (LOPES NETO, 2005 , p. l)

Para esse autor, visando ao combate à violência, o trabalho de conscientização na escola deve envolver os profissionais responsáveis, alunos e as famílias. A experiência mostra que é preciso realizar um trabalho continuado. A escola deve garantir segurança não somente em relação à violência externa, como também viabilizar a convivência sadia entre os estudantes" (LOPES NETO, 2005, p. 2).

O mesmo autor afirma, então, que o papel das famílias é fundamental para reduzir a ocorrência e os danos provocados pelo fenômeno:

\begin{abstract}
A família tem uma participação muito importante, não só para identificar, como para evitar as causas do problema [...]. Crianças educadas com violência, física ou moral vão reproduzir as mesmas condições em seus relacionamentos fora de casa. Se não se tornarem agressores, podem ter a auto-estima afetada, acreditando que são realmente inferiores e que merecem o tratamento agressivo que venham a receber dos outros. [...] A diferença está na forma de ocorrência, que varia de acordo com os valores e a cultura. (LOPES NETO, 2005, p. 3)
\end{abstract}

Esse autor explica que nas escolas de estudantes de baixa renda os critérios de discriminação passam pelas condições da roupa, mochila, tênis, além de características físicas, como "orelhas de abano", uso de óculos, tipo de cabelo, cor da pele ou comportamento diferente em relação à maioria. Bons alunos são chamados de nerds, cristalizando uma imagem que é vista de forma negativa pelos colegas. 
Nas classes de maior poder aquisitivo, uma das principais formas que fundamentam a violência é a diferença entre bens materiais.

De acordo com Lopes Neto (2005), o hábito de comparar os tipos de carros que deixam os estudantes na escola, por exemplo, ressalta atitudes de preconceito e discriminação: a intenção é idêntica, o que varia é a forma de agredir. Nesse sentido, de acordo com o entendimento do autor, as formas de atividades sublimatórias, devem ser consideradas segundo a demanda de cada escola e as características do grupo escolar, visto que cada indivíduo possui suas singularidades e subjetividades as quais devem ser respeitadas no momento do planejamento das ações.

Logo, uma forma de combater esses comportamentos, seria fornecer possibilidades de sublimação dessa agressividade em outras atividades escolares, bem como o apoio familiar. A violência presente nas escolas e na vida de várias famílias pode ser evitada pela sociedade, conjuntamente com as escolas e as famílias em prol do futuro da civilização.

Acredita ser uma questão de conscientização, divulgação e, sobretudo, de boa vontade, persistência e, sobretudo, de cidadania - deveres e direitos.

\section{Aspecto Sociopsicológico}

As vítimas da violência psicológica, quase sempre, não podem contar com a ajuda de seus colegas. Embora digam repudiar esse tipo de violência e sentirem pena, declaram que nada podem fazer para defendê-las, com medo de serem a próxima vítima. Muitas crianças desenvolvem medo, pânico, depressão, distúrbios psicossomáticos e geralmente evitam retomar a escola quando esta nada faz em defesa da vítima. A fobia escolar geralmente tem como causa algum tipo de violência psicológica.

Nesse sentido, segundo Lopes Neto (2005), a maioria desses casos ocorre no interior das salas de aula, sem o conhecimento do professor. Além de conviver com um estado constante de pavor, a criança ou adolescente são os que mais sofrem com a rejeição, isolamento, humilhação, a tal ponto de se verem impedidos de se relacionarem com quem desejam, de brincarem livremente, de fazerem a tarefa na escola em grupo.

Segundo esse autor, também faz parte dessa violência impor à vítima o silêncio, isto é, ela não pode denunciar à direção da escola nem aos pais, sob pena de piorar sua condição de discriminada.

Assim, pais e professores só ficam sabendo do problema através dos efeitos e danos causados, como a resistência em voltar à escola, queda de rendimento escolar, retraimento, depressão, distúrbios psicossomáticos, fobias etc.

Talvez o pior efeito da pressão sofrida nesses casos é a vítima se sentir condenada à "inexistência", ou à "invisibilidade", geralmente levado a cabo por grupo que combina, entre si, ignorar um colega, fazer de conta que ele não existe, desqualificá-lo na sua competência intelectual, ou rejeitar um pedido seu etc. Há casos em que esse tipo de vítima passa a sofrer tão baixa autoestima que nem sequer tem forças para desabafar com alguém. Por outro lado, existem casos em que a vítima aprende a conviver com a situação se tornando uma voluntária servil do dominador.

Quando a violência ocorre na escola, cabe aos pais conversar com a direção. É dever da instituição ensinar os conhecimentos e promover a inclusão social e psicológica. A escola jamais deve fazer "vistas grossas" sobre os casos de intolerância de violência psicológica ou física. A escola deve ter uma atitude preventiva contra essa violência, começando pela conscientização e preparação de professores, funcionários, pais e alunos. Portanto, por um lado, é preciso apoiar as crianças vítimas, e por outro, é imprescindivel fazer um trabalho especial com as pessoas propensas a cometer violência contra os colegas, professores e funcionários.

Segundo Lopes Neto (2005), os pais e professores devem estar atentos sobre a possibilidade real de conviver com uma vítima silenciosa 
de qualquer tipo de violência, como também conviver com o(s) agente(s) dessa violência. Criança ou adolescente que repete atos de intolerância e de violência para com o próximo pode estar sendo "autorizada" pelos pais - que a veem positivamente como "esperta", "machão", "bonzão" etc. É preciso estar muito atento aos grupinhos informais de traços neofascistas, as gangs, porque a afirmação da sua identidade narcísica é conseguida por meio da intolerância, da discriminação e da violência.

Para o mesmo autor, existe uma relação de continuidade entre a criança cuja estrutura psíquica é perversa, que cometia atitudes antissociais, e o adulto que comete atos delinquentes ou criminosos. A estrutura psíquica é a mesma. São casos em que a educação falha, embora o sujeito possa obter algum sucesso na sua vida escolar e profissional. Adquirir conhecimento ou um título de "doutor" nada tem a ver com adquirir sabedoria. Por vezes, encontram-se pessoas cujo conhecimento fez aumentar sua arrogância e insensibilidade em relação ao próximo. Ou seja, embora a formação escolar e universitária não tenha o poder de melhorar a estrutura psíquica do tipo perversa, é preciso trabalhar com cálculo e empatia para formar bons cidadãos. Quando se pode proporcionar tanto uma educação (familiar) quanto um ensino (escolar), voltados mais para a sabedoria do que para o conhecimento e a informação, é possível trilhar um caminho mais efetivo de prevenção em prol da saúde psicológica e social.

Para Fante (2005), as causas desse tipo de comportamento abusivo são inúmeras e variadas. Deve-se, dentre outras, à necessidade de reproduzir contra outros os maus-tratos sofridos em casa ou na escola, provocando irritabilidade, agressividade, indisciplina, impulsividade, intolerância, tensão, explosões emocionais, raiva reprimida, depressão, stress, entre outros.

É oriunda do modelo educativo predominante introjetado pela criança na primeira infância. Sendo repetidamente exposta a estímulos agressivos, aversivos ao seu psiquismo, a criança os introjeta inconscientemente ao seu repertório comportamental e trans- forma-se posteriormente em uma dinâmica psíquica "mandante" de suas ações e reações. Dessa forma, tornar-se-á predisposta a reproduzir a agressividade sofrida ou a reprimi-la, comprometendo, assim, seu processo de desenvolvimento social. As consequências para as "vítimas" desse fenômeno são graves e abrangentes, promovendo no âmbito escolar o desinteresse pela escola, o deficit de concentração e aprendizagem, a queda do rendimento, o absentismo e a evasão escolar. No âmbito da saúde física e emocional, a baixa na resistência imunológica e na autoestima, o stress, os sintomas psicossomáticos, transtornos psicológicos, a depressão e o suicídio.

Esclarece, ainda, a mesma autora que para os "agressores" ocorre o distanciamento e a falta de adaptação aos objetivos escolares, a supervalorização da violência como forma de obtenção de poder, o desenvolvimento de habilidades para futuras condutas delituosas, além da projeção de condutas violentas na vida adulta. As "vítimas" se sentem inseguras, daí a ansiedade, medo e estresse, comprometendo o processo socioeducacional. Esse fenômeno comportamental atinge uma área preciosa do ser humano, íntima e inviolável do ser, a sua alma. A forte carga emocional traumática da experiência vivenciada, registrada em seus arquivos de memória, poderá aprisionar sua mente a construções inconscientes de cadeias de pensamentos desorganizados, que interferirão no desenvolvimento da sua autopercepção e autoestima, comprometendo sua capacidade de autossuperação na vida.

Dependendo do grau de sofrimento vivido pela criança, ela poderá sentir-se ancorada a construções inconscientes de pensamentos de vingança e de suicídio, ou manifestar determinados tipos de comportamentos agressivos ou violentos, prejudiciais a si mesma e à sociedade, isso se não houver intervenção diagnóstica, preventiva e psicoterápica, além de esforços interdisciplinares conjugados, por toda a comunidade escolar. Desta forma, conclui-se, pelo exposto neste tópico, que medidas preventivas devem ser tomadas envolvendo a tríade: governo-família-escola. 


\section{Perspectivas da Educação}

Segundo Gadotti (1993), no sentido primitivo, a palavra educação tem suas origens nos verbos latinos educare (alimentar, amamentar, criar), com significado de algo que se dá a alguém, e educere, que expressa a ideia de conduzir para fora, fazer sair, tirar de. Nessa acepção, educação representa um ato a desenvolver, de dentro para fora, algo que está no indivíduo. O sentido educere sugere a libertação de forças latentes e que dependem de estimulação para virem à tona.

De acordo com Guimarães (1996), a dinâmica que a educação para a paz tem assumido, nos últimos anos, aponta para uma multiplicidade de práticas e de sentidos que se configuram não apenas plurais, mas, muitas vezes, antagônicos, configurando um verdadeiro conflito de interpretações e levantando a própria questão do seu sentido, possibilidade e densidade. A racionalidade hermenêutica, com seu pressuposto de que o sentido é explicável somente a partir de nossa pertença a uma tradição que se constitui como comunidade de sentido, aponta à educação para a paz como um acontecimento coletivo, mediado por um grupo, integrado em rede com outros grupos, no qual as referências pacifistas da cultura da paz e do movimento pacifista são presentificadas pelos diversos elementos que a constituem, como o tempo vivido, o espaço estruturado, os jogos de linguagem, os elementos lúdicos etc.

E, conforme Estrela (1998), no momento atual, a violência é um fenômeno que se observa com frequência crescente em todos os domínios da vida social. Como não poderia deixar de ser, esse fenômeno também ocorre na escola, onde professores e alunos vivenciam, no seu cotidiano, diferentes formas de violência. Pesquisas realizadas sobre a temática relatam suas manifestações, procurando entender as raízes socioculturais, econômicas e familiares do fenômeno.

Existe grande perplexidade da parte do professor que, muitas vezes, fica sem saber como agir para resolver e prevenir os múl- tiplos conflitos que surgem no cotidiano escolar. $\bigcirc$ que se observa é que, na maioria das vezes, ele tem muitas dificuldades de lidar com as situações de conflito, de forma a propiciar ao aluno experiências educativas de interação social construtiva que favoreçam a sua formação ética e minimizem a violência na escola. Em contrapartida, pensamos que a escola é o espaço por excelência em que o indivíduo tem possibilidades de vivenciar de modo intencional e sistemático formas construtivas de interação [...]. (GONÇALVES et al., 2005, p. 2)

Desta forma o indivíduo adquire um saber que propicia condições para o exercício da cidadania. Segundo o site da UNESCO - Organização das Nações Unidas -, para a Educação, a Ciência e a Cultura, quando ela foi fundada, seu célebre preâmbulo apontava para a relação entre paz e cultura; para a percepção de que a incompreensão entre os povos e a desconfiança entre as nações está na raiz das guerras e para a consciência da necessidade de fundar a paz num núcleo intelectual e moral. Postulava que, se as guerras nascem no espírito dos homens, é no espírito dos homens que devem ser construídas as defesas da paz.

Em 1986, pesquisadores do mundo todo, convocados pela UNESCO, lançaram o Manifesto de Sevilha, assinalando claramente sua posição contra um certo número de presumidos descobrimentos biológicos que foram utilizados por pessoas, inclusive em nossos respectivos âmbitos, para justificar a violência e a guerra e afirmando que a biologia não condena a humanidade à guerra.

Assumido posteriormente pela $25^{\mathrm{a}}$ Conferência Geral da UNESCO, em 1989, tomou-se importante para elaboração do conceito de cultura de paz, ao afirmar que a mesma espécie que inventou a guerra é capaz de inventar a paz. Estas foram suas cinco declarações:

- É cientificamente incorreto dizer que se herda de antepassados animais uma propensão para fazer a guerra; 
- É cientificamente incorreto dizer que guerra ou qualquer outra forma de comportamento violento está geneticamente programado na natureza humana;

- É cientificamente incorreto dizer que ao longo da evolução humana se operou uma seleção em favor do comportamento agressivo sobre outros tipos;

- É cientificamente incorreto dizer que os homens têm um cérebro violento;

- É cientificamente incorreto dizer que a guerra é um fenômeno instintivo que responde a um único móvel.

Porém, cabe observar que nem todos agiram/ agem de forma científica e politicamente correta

\section{Por uma Cultura de Paz}

A cultura global favoreceu a percepção das necessidades mundiais e o desenvolvimento de tecnologias da comunicação possibilitou a integração e a interdependência entre os membros do planeta (GUIMARÃES, 2000b).

A paz tem emergido, hoje, não apenas como clamor universal, mas como um dos campos onde opera um certo consenso, no qual a civilização ocidental exprime sua ideia de bem. Os estudos sobre a paz começam a se libertar do domínio dos estudos militares e políticos ou sobre a guerra, para ganhar autonomia e abrangência própria. A própria problemática da paz está sendo circunscrita de forma abrangente, desde questões do psiquismo humano ou da organização socioeconômica e política, atingindo também o plano cultural. As análises compreendem desde a recusa categórica de que a guerra esteja inscrita no programa genético humano até a proposição de novas perspectivas, passando pelo desvelamento dos mecanismos de formação de uma cultura de violência e pelo conhecimento do papel de certas agências, na expressão e produção da cultura de violência (GUIMARÃES, 2000b, p. 3)
O conceito de cultura de paz reconhece que a paz tem, além de raízes sociais, econômicas e políticas, uma base cultural.

A cultura, por um lado, diz respeito às expressões produzidas e criadas pela humanidade e, portanto, como uma realidade ligada ao ato de aprender, criar, transmitir, educar; por outro, como aquilo que subjaz a estas mesmas expressões. Aqui o conceito de paradigma - como uma realidade que é lógica, pré-lógica, supralógica - poderia ser esclarecedor. (GUIMARÃES, 2000b, p. 3)

E é exatamente nesse sentido que a reflexão sobre cultura de paz deve ser conduzida, ou seja, por meio de transição ou mudança de paradigmas.

É importante detectar os processos culturais de produção da violência, pois as pessoas vivem em uma sociedade de culturas violentas produzidas e difundidas por inúmeras instâncias da sociedade: os meios de comunicação, a escola, a família, as instituições religiosas, os partidos políticos, os clubes, os sindicatos etc.

De acordo com Appel (1982), existe um currículo oculto conceituado, como a distribuição tácita pela escola de normas, valores, tendências e conhecimentos educacionais aceitos de maneira inconsciente.

Segundo Galeano (1999, p. 5), "Os países responsáveis pela paz universal são os que mais armas fabricam e os que mais armas vendem aos demais países [...]".

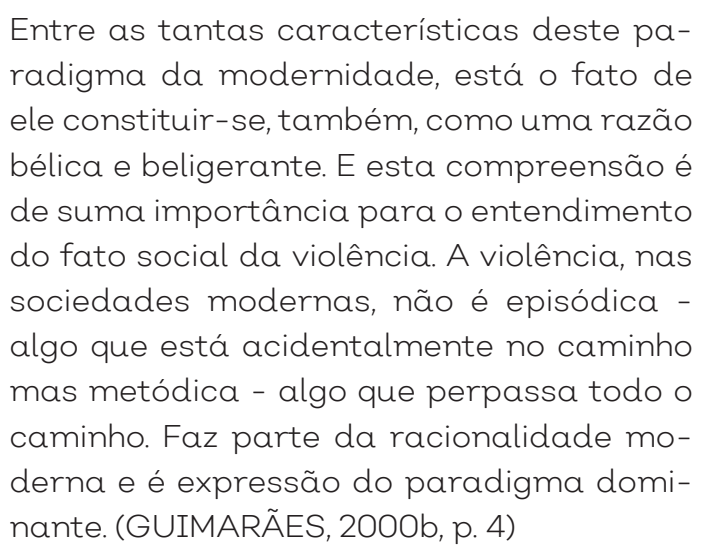

As promessas de paz formuladas pela modernidade: 
[...] não só não foram cumpridas - (enquanto no século XVIII morreram $4.4 \mathrm{mi}$ lhões de pessoas em 68 guerras, no nosso século morreram 99 milhões de pessoas em 237 guerras), mas levou ao desenvolvimento tecnológico da guerra e ao aumento sem precedentes do seu poder destrutivo. (SANTOS, 2000, p. 56)

A história do século XX foi "[...] a era das ilusões perdidas e que nela mataram-se mais seres humanos do que em qualquer outra época e nela se chegou a níveis de bem-estar jamais vistos na experiência humana" (HOBSBAWN, 1999, p. 15).

A violência não é, entretanto, a última palavra dada. Nesse sentido, segundo Santos (apud HOBSBAWN, 1999, p. 16), "[...] entre as ruínas que se escondem atrás das fachadas, podem pressentir-se os sinais, por enquanto vagos, da emergência de um novo paradigma".

Diante de notícias da mídia afirmando que a violência tem crescido, desenha-se um novo senso comum emancipatório e uma prática societal eminentemente não violenta.

Este paradigma pode ser vislumbrado em documentos, tais como a Declaração Universal de Direitos Humanos - patamar qualitativo da história da humanidade operando e estabelecendo um consenso em torno da dignidade humana; no sem número de organizações que constituem atualmente o movimento pacifista e que tem trabalhado em campos, como a luta contra o armamentismo, a luta pela cidadania, a educação para a paz, a contestação do serviço militar obrigatório, o campo da não- violência. a solidariedade aos povos em conflitos; em uma série de movimentos - como os sociais, feminista e de afirmação sexual, ecológico, de afirmação cultural, de libertação. Este conjunto todo deu essencial contribuição na construção de um novo senso comum civilizatório. (GUIMARÃES, 2000b, p. 4)

Para esse autor, exercitar-se numa nova compreensão é pensar na paz da seguinte forma:

- Mais como positividade do que negatividade: trata-se, em primeiro lugar, de superar o conceito ocidental de paz como ausência de algo, notadamente como ausência de guerra ou de perturbação, para um conceito mais positivo, associado a experiências humanas, tais como justiça e igualdade.

\section{- Como uma construção do que um estado:} a paz não é um estado dado, mas algo a ser instaurado e construído pelas pessoas, da qual não são seus clientes ou seus beneficiários, mas os sujeitos e cocriadores.

Aqui entra a noção do consenso que necessita ser instaurado e operado.

- Multiculturalmente: a cultura de paz no plural, ou seja, "culturas de paz".

- Como uma realidade intersubjetiva: a paz deixa de ser um atributo individual, vislumbrada em afirmações de se estar ou ter paz, para assumir uma compreensão mais coletiva e comunitária, como evento do ser-no-mundo. A paz não é uma construção individual ou isolada. A paz se constrói a partir do horizonte do pacifismo, isto é, do engajamento em um movimento organizado, articulado e estruturado em prol da paz. Falar em movimento é evocar pessoas em movimento, contatos pessoais e grupais. Trata-se mais fundamentalmente de estabelecer relações do que formar atitudes.

Como uma agenda para a paz: trata-se de superar a abstração geralmente associada ao conceito: paz pode significar tudo e, por isso, não significa nada. É importante também que as pessoas se desprendam das ligações entre paz e passividade, entre pacífico e passivo. Daí a importância de agregar à noção uma agenda bem definida.

Atualmente, o movimento pacifista agrega à luta pela paz algumas bandeiras bem definidas, tais como: luta contra armamentismo; solidariedade para com os povos em conflito; direitos humanos e cidadania, educação para a paz.

Assim tem-se que a paz:

[...] é uma criação do exercício generoso do diálogo entre as pessoas que não pode ser outorgado. Um dever de direitos que nos 
cabe. por quem somos individual e coletivamente responsáveis, seres da sociedade, dos povos e nações da Terra. [...] tampouco existe uma única paz, uma única idéia universal de paz. uma, portanto, possibilidade de proposta única de uma cultura de paz [...] superando o etnocentrismo e a uniculturalização. (BRANDÃO, 1995, p. 48-54)

Enfim, edificar uma cultura de paz requer como prioridade viabilizar o respeito aos direitos humanos, que, por sua vez, são necessários e complementares na cultura da paz. Nesse sentido, a cultura da paz supõe lutar contra a guerra e a violência, a pobreza e a injustiça. Para isso, é preciso imbuir-se de uma cultura de violência para uma cultura de paz requer, além de tudo, promover a participação e empoderamento de todos os setores da sociedade. É preciso enfrentar a discriminação e a exclusão social, assim como transcender as imagens do "outro", para compreender a divergência e apreciar a diversidade. Nesse movimento, a educação e a tecnologia são fundamentais. Isso, naturalmente, com a participação efetiva da família e comunidade.

\section{Conclusão}

Considerando-se que os seres humanos são condicionados, mas não determinados, tem-se que a história é sempre um tempo de possibilidades. Enquanto humanos, as pessoas representam uma presença por inteiro - com corpo, ideias, afirmações, negações - e não podem escapar à responsabilidade ética dessa presença.

Portanto, educadores presentes no contexto pedagógico, quando negligenciam o lugar do corpo, da alegria, do diálogo, do estudo e da profundidade da análise, estão colaborando para a construção de uma concepção de educação.

Recusar ao sonho e à utopia significa imobilizar o ser humano. Porém, não se olvidar da completude do ser humano, no reconhecimento de sua constante procura, de sua curiosidade e de sua capacidade de transformar. Portanto, educar não é treinar, não se reduz a classificar e registrar notas e/ou conceitos.
O caminho para a paz é pedregoso e está cheio de empecilhos. Ora se peca pelo excesso de otimismo, desembocando em soluções utópicas, ora pelo excesso de pessimismo, levando a soluções que impedem a própria paz. Concretamente pensa-se no pacifismo sem limites.

Construir a paz é uma das tarefas mais especificamente humanas; pois não se nasce com a paz no sangue, precisa-se aprendê-la, plantá-la no coração e formar pessoas para ela a cada dia. A paz é, então, um anseio acalentado com teimosia no coração humano, não obstante parecer ela uma exilada sempre de malas prontas para migrar a outras terras. A paz não é fruto de um fatalismo benfazejo, nem de qualquer voluntarismo solitário. Demanda misteriosa cumplicidade de inteligência e coração, de indivíduos e grupos, que resulta num caldo cultural que é a cultura da paz. Esta se constitui de intrincada rede de participações que a ninguém deixa excluído nem diminuído. A paz é uma utopia a ser construída sempre, enquanto não chegar à plenitude messiânica definitiva. Pode-se compará-la ao ato de andar de bicicleta: para manter-se de pé, tem que se estar sempre em movimento.

Não são poucos os que a procuram. A paz vem sendo tecida e perseguida em múltiplos teares e oficinas, em diferentes esferas e caminhos, nos recantos mais inopinados e com os nomes mais exóticos. Há uma fermentação de movimentos e iniciativas, de gestos e bandeiras voltados para a paz. São pouco conhecidos porque a cultura vigente prefere publicar a guerra e silenciar a paz; mas eles existem e persistem em tecer a frágil teia preciosa da paz. Assim, torná-los conhecidos - ou ainda melhor, filiar-se a algum deles - é multiplicar sua força, não os deixando esmorecer. Daí a importância da união.

O coração é dividido. Dele nasce a entrega até a morte pelo outro. Dele nasce também a rejeição até à morte do outro. Somos um enigma metafísico, contradição viva, anjo e demônio convivendo dentro do mesmo espaço vital. Numa palavra, somos a consciência dos opostos. Por isso, a construção da paz como um aprendizado só será possível na medida em que as pessoas 
individualmente e as coletividades se predispuserem a darem mais espaço e a cultivarem de forma consciente e organizada a dimensão de hospitalidade, de convivência, de respeito, de cooperação, de solidariedade e de amor. A cultura da paz depende da predominância dessas positividades e do cuidado que todos mantiverem com a outra dimensão, sempre presente, de rivalidade, de egoísmo e de exclusão dos demais.

Para aplacar a violência nas escolas é preciso que se estabeleçam limites. Limite tem sido uma palavra que está em alta na sociedade atualmente e especificamente como uma preocupação dentro da escola. Não se pode culpar as crianças/adolescentes, ou melhor, somente elas, por seu comportamento violento, é preciso lembrar que a sociedade reflete sobre a geração mais nova, e a sociedade atual como um todo perdeu os parâmetros sobre a questão dos limites quanto ao respeito, à disciplina, ou até mesmo, à retidão moral, na construção de um novo cidadão crítico, participativo e autônomo.

A pesquisa de campo foi realizada em estabelecimentos de ensino pertencentes à zona urbana de Fortaleza dos Nogueiras, uma cidade de pequeno porte do sul do Maranhão, com aproximadamente 13.000 habitantes em toda a extensão territorial. Detectou-se que os alunos em consonância com professores e administração encontram muitas dificuldades em virtude da perda de referenciais, seja a nível familiar, seja institucional.

Há muitas expressões de violência numa cultura que sempre teve o domínio dos coronéis (dominação tradicional, segundo Weber), dominação de Igrejas, principalmente evangélicas (dominação carismática), e a dominação legal dos poderes constituídos. Prevalece a lei dos favores e dos "apadrinhamentos". Não se sabe bem como lidar com a liberdade, com a democracia e com o "diálogo". Por exemplo: mata-se por nada, por briga de infância, porque um bêbado agrediu verbalmente alguém etc.

Parece que a pessoa "eleva-se" pelo comportamento vulgar, quanto mais palavrões, mais violações às leis, mais mostra seu poder.
Entre as crianças não é diferente. Parece que se perderam os referenciais. Como se trata de um meio mais rural, é comum as crianças apelidarem-se pejorativamente de nomes de animais: jararaca, sapo, onça, perereca, morcego etc. Os professores também não sabem como lidar com tantas situações diferentes e divergentes. As famílias cobram da escola, mas, na maioria, não contribuem. Essa situação precisa mudar.

Finalizando, cabe frisar que pelo pesquisado e explicitado se tenha diagnosticado a problemática inicial: Como se poderia reverter a violência de forma que a paz volte a reinar no ambiente escolar? Simplesmente através da afetividade, trabalho integrado entre famílias, escola e comunidade, programas sérios a nível governamental e não governamental, cumplicidade, solidariedade e muito amor.

\section{Referências}

ALVES, Z. M. M. B. Crianças e adolescentes: a questão da tolerância na socialização das gerações mais novas. In: ALVES, Z. M. M. B; FISCHMAN, R. (org.). Crianças e adolescentes: construindo uma cultura da tolerância. São Paulo: EDUSP, p. 79-93, 2001.

ANDRADE, M. M. de. Introdução a metodologia do trabalho científico. 6. ed. São Paulo: Atlas, 2003. ANTUNES, C. Disciplina e indisciplina na escola. Palestra. CD-ROM, 2005.

APPEL, M. Ideologia e currículo. São Paulo: Brasiliense, 1982.

AQUINO, J. R. G. (org.). Indisciplina na escola: alternativas teóricas e práticas. São Paulo: Summus, 1996.

ARENDT, H. Sobre a violência. Trad. de André Duarte. 2. ed. Rio de Janeiro: Relume Dumará, 2000. BOTTOMORE, T. Dicionário do pensamento marxista. Rio de Janeiro: Zahar, 1988.

BRANDÃO, C. R. Em campo aberto: escritos sobre a educação e a cultura popular. São Paulo: Cortez, 1995.

CANDAU, V. M.; LUCINDA, M. da C.; NASCIMENTO, M. das G. Escola e violência. Rio de Janeiro: DP\&A, 1999. 
CHAUÍ, M. Convite à filosofia. 3. ed. São Paulo: Ática, 1995.

DEMO, P. Metodologia científica em Ciências Sociais. São Paulo: Atlas, 1995.

DICIONÁRIO AURÉLIO ELETRÔNICO: Século XXI. Rio de Janeiro: Nova Fronteira e Lexicon Informática, 1999. CD-ROOM.

ESTRELA, M. T. Relação pedagógica, disciplina e indisciplina na aula. 3. ed. Porto: Porto, 1998.

FANTE, C. Fenômeno bullying. São Paulo: Verus, 2005.

FERREIRA, A. B. de H. Novo Dicionário da Língua Portuguesa. 20. ed. Rio de Janeiro: Nova Fronteira, 1986.

GADOTTI, M. A. Educação contra a educação: o esquecimento da educação e a educação permanente. Rio de Janeiro: Paz e Terra, 1993.

GALEANO, E. De pernas pro ar: a escola do mundo ao avesso. Porto Alegre: LPM, 1999.

GARDNER, H. Inteligências múltiplas: a teoria na prática. Porto Alegre: Artes Médicas, 1995.

GIL, A. C. Métodos e técnicas de pesquisa social. São Paulo: Atlas, 2002.

GIL, M. O que é Inclusão Social? (1997). Disponível em: <http://www.tvebrasil.com.br/SALTO/boletins2002/ede/edetxtl.htm>. Acesso em: 10/07/2007. GONCCALVES, M. A. S. et al. Violência na escola, práticas educativas e formação do professor. Caderno de Pesquisas, São Paulo, v. 35, n. 126, set./dez. 2005.

GUIMARÃES, Á. A dinâmica de violência escolar: conflito e ambigüidade. Campinas: Autores Associados, 1996.

GUIMARÃES, M. R. Se queres a paz, prepara-te para a paz. (2000a). Disponível em: <http://www. al.rs.gov.br/eventos/paz/texto8.htm>. Acesso em: 08/07/2007.

AGÊNCIA INTERNACIOANL PELA PAZ (IPAZ). Por uma Cultura de Paz. (2000b). Disponível em: <http://www.ipaz.org/lermais_materias.php?cd_materias $=13>$ Acesso em: 11/07/2007.

GUIMARÃES, M. R. A educação para a paz como exercício da ação comunicativa: alternativas para a sociedade e para a educação. Educacão, Porto Alegre/RS, ano 24, n. 2, p. 329-368, mai./ago. 2006. Disponível em: <http://revistaeletronicas.pucrs.br/faced/ojs/includ/getdoc. php?id $=239 \&$ article $=82 \&$ mode $=$ pdf. $>$. Acesso em: 07/07/2007.

HOBSBAWN, E. A era dos extremos. São Paulo: Companhia das Letras, 1999.

LA TAILLE, Y. de. Limites: três dimensões educacionais. 3. ed. São Paulo: Ática, 2003.

LOPES NETO, A. A. Bulliyng. (2005). Disponível em: <http://www.uff.br/saudecultura/encontros/ Bullyng.pdf>. Acesso em: 30/09/2019.

MORIN, E. Os sete saberes necessários à educação do futuro. São Paulo: Cortez, 2000.

PORTELA, C. P. de J. A configuração das relações entre pais de crianças surdas e escola. In: JACQUET, C.; COSTA, L. A. F. da. (org.). Familia em mudança. São Paulo: Companhia Ilimitada, 2004. p. 85-107.

Família e escola: como essa parceria pode favorecer crianças com necessidades educativas especiais. In: DIAZ, F. et al. (org.). Educação inclusiva, deficiência e contexto social: questões contemporâneas. Salvador: EDUFBA, 2009. p. 149-159.

As práticas educativas e a pluralidade familiar contemporânea. In: Anais... II Seminário Internacional em família contemporânea: natureza e cultura 20 a 22 de setembro de 2010. Salvador: UCSAL, MIDIA CD-ROM, 2010.

Famílias de crianças com deficiência e redes sociais. In: Anais... VII Encontro da Associação Brasileira de Pesquisadores em Educação Especial. Londrina: MIDIA CD-ROM, 2011. p. 1.257-1.265

As práticas educativas no contexto dos lares reconstituídos. In: NASCIMENTO, E. de S.; CORREIA, P. C. da H. Dialogando com a inclusão: curso de formação de professores. Recife: Liceu, 2012. p. 193-2004.

NASCIMENTO, E. S.; CORREIA, P. C. H. (org.). Dialogando com a inclusão II: curso de formação de professores. Recife: Liceu, 2014. 